\title{
PENGEMBANGAN DESTINASI WISATA DI SUBDISTRIK TUTUALA, TIMOR LESTE
}

\author{
Tomas Pereira \\ Dili Institute of Technology, Timor Leste
}

\begin{abstract}
Tutuala is one of the subdistricts of Lautem in East Timor that rich in natural beauty, history and culture. This study aimed to indentify the potential of tourism in the sub-district of Tutuala as a tourist attraction. It also examine the perception of tourist toward the potentials to formulate strategies and programs for tourism development in Tutuala. The data used in this study was qualitative data that were obatined through observation, interview, questionnaire and documentary studies. The number of respondents in this study consisted of 30 samples divided into 4 informants and 26 respondents. The determination of samples was made by accidental sampling and purposive sampling methods. The analytical method used qualitative descriptive and SWOT analysis. The research findings show that the tourism potential possessed by Tutuala are very potentials to develop as touriss attraticons. Some stratetgies are suggested to develop Tutuala including mapping program for tourism potential, inventorying program for objects and tourist attraction, program for the development of facilities and infrastructure supporting tourism, program for environment security, program for formation of institutions and education in the field of tourism, extension programs for tourism awareness.
\end{abstract}

Keywords: development destination, tourism potential, SWOT analysis, Tutuala Subdistrict

\footnotetext{
Abstrak

Tutuala adalah salah satu kecamatan dari Lautem di Timor Timur yang kaya akan keindahan alam, sejarah, dan budaya. Penelitian ini bertujuan untuk mengidentifikasi potensi pariwisata di sub-distrik Tutuala sebagai objek wisata, persepsi wisatawan, dan strategi untuk pengembangan pariwisata di Tutuala. Data yang digunakan dalam penelitian ini adalah data kualitatif yang dikumpulkan melalui studi observasi,
} 
wawancara, penyebaran kuesioner, dan kajian dokumen. Jumlah responden dalam penelitian ini terdiri dari 30 sampel dibagi menjadi 4 informan dan 26 responden. Penentuan sampel dilakukan dengan accidental dan purposive sampling. Metode analisis yang digunakan kualitatif analisis deskriptif dan SWOT. Hasil penelitian menunjukkan bahwa potensi pariwisata yang dimiliki oleh Tutuala sangat potensi untuk dikembangkan sebagai straksi wisata. Beberapa strategi yang disarankan adalah program pemetaan potensi wisata, pengembangan objek dan daya tarik wisata, inventarisasi untuk pengembangan sarana dan prasarana pendukung pariwisata, program keamanan lingkungan, pembentukan institusi dan pendidikan di bidang pariwisata, dan sadar wisata.

Kata kunci: tujuan pembangunan, potensi wisata, analisis SWOT, Kecamatan Tutuala

\section{Pendahuluan}

Pariwisata merupakan aktivitas, pelayanan dan produk hasil industri pariwisata yang mampu menciptakan pengalaman perjalanan bagi wisatawan. Pariwisata perlu dikembangkan sebagai salah satu produk yang menguntungkan bagi pengembangan perekonomian ke depan. Oleh karena itu, potensi yang dimiliki pada setiap negara merupakan salah satu aset yang dapat dijadikan sebagai suatu produk yang sangat menguntungkan, sebab potensi wisata merupakan daya tarik yang terkandung dalam suatu daerah yang memiliki keindahan serta keragaman budaya yang unik yang mampu menarik minat wisatawan dalam mengunjungi suatu negara (Muljadi, 2012:5).

Sektor pariwisata, perdagangan dan industri menjadi pilar yang sangat penting bagi negara subsektor pembangunan yang diandalkan dalam pembangunan suatu negara. Tiga pilar tersebut menjadi sumber daya yang perlu dikembangkan untuk memajukan suatu negara dari kondisi yang masih miskin menuju ke negara yang maju atau kaya. Begitu pula dengan negara Timor-Leste yang termasuk dalam kategori negara sedang berkembang menggunakan sektor perminyakan dan sektor-sektor lainnya sebagai sektor yang diadalkan salah satunya adalah pariwsata.

Pariwisata di Timor-Leste memiliki potensi sangat menarik bagi wisatawan untuk mengunjunginya, tetapi masih ada berbagai masalah yang dihadapi bagi pemerintah dan para investor sebagai faktor penghambat, beberapa di antaranya adalah infrastruktur, sumber daya manusia dan biaya, sebab banyak potensi pariwisata yang dimiliki yaitu destinasi wisata dari keindahan dan keasliannya sebagai salah satu faktor pendukung 
(Lay, 2012:2). Pariwisata Timor-Leste sekarang ini masih dalam tahap pembangunan, maka dari itu, efektif, efisien dan keunikan menjadi hal penting bagi kementrian pariwisata Timor-Leste dan stakeholder dalam menyiapkan paket-paket wisata, bila tidak demikian maka citra pariwisata Timor-Leste akan hilang di mata wisatawan manca negara (Word Bank, 2012:8). Tingkat kunjungan wisatawan ke Timor-Leste menujukkan bahwa dari tahun ke tahun terdapat peningkatan wisatawan yang berkujung hal tersebut terbukti seperti dari tahun 2007 (6176) wisatawan sampai 2011 (38341) wisatawan. Tahun 2012 terjadi penurunan terhadap kujungan wisatawan yaitu hanya terdapat 25215 wisatawan, hal itu terjadi karena di tahun tersebut Timor-Leste terjadi masalah politik antara beberapa partaipartai politik yang menyebabkan keamanan di Timor-Leste kurang stabil sehingga minat wisatawan yang berkunjung menurun. Tahun 2013 kunjungan wisatawan mulai meningkat hingga tahun 2014, hal tersebut terjadi karena pada tahun 2013 Timor-Leste mengadakan event besar seperti pertemuan negara-negara berbahasa Portugis (CPLP), Dili Internasional Dialog, Timor-Leste development patner meeting (TLDPM) dan Caravana artistic, maka dari itu sangat memberikan dampak kepada pemerintah pariwisata untuk lebih bekerja keras dalam perencaan pengembangan pariwisata yang dilakukan sebab hal-hal yang perlu dilaksanakan saat ini adalah menambah akomodasi, perbaikan jalan raya, pengembangan destinasi wisata dan lain sebagainya.

Subdistrik Tutuala terletak paling timur di negara Timor-Leste, jarak yang ditempuh dari pusat kota Dili menuju Tutuala $\pm 275 \mathrm{~km} / \pm 8$ jam. Luas wilayah distrik ini 1,702.33 kilometer persegi, yang dibagi lagi menjadi lima kecamatan dan memiliki tiga suku utama yakni tiap-tiap suku mempunyai bahasa masing-masing yaitu suku Fataluku, suku Makasae dan suku Makalero. Subdistrik ini selain memiliki keindahan pantai juga memiliki potensi ekologi, panorama alam, flora dan fauna yang hidup dan berkembang dan wisata budaya berupa upacara ritual meci, kerajianan tradisional tais (kain tradisional), keramahtamahan penduduk lokal pada acara-acara tertentu dan juga nilai-nilai sejarah seperti tempat-tempat penting dan bersejarah dari penjajahan Portugis. Subdistrik Tutuala dalam pengembangan dan perencanaan pariwisata untuk tahun 2015 sampai 2022, pemerintah menetapkan bahwa salah satu pengembangan yang dilaksanakan adalah; jalan raya, air bersih, listrik, telekomunikasi, hotel dan restoran serta atraksi budaya seperti tarian tradisional, kuliner dan ritual Goa Ili kere-kere (Medina, 2015).

Salah satu aktraksi wisata yang paling dikenal di Subdistrik Tutuala adalah upacara ritual adat penangkapan meci. Meci merupakan sebutan nama bahasa daerah masyarakat Tutuala yang diterjemahkan ke dalam bahasa Indonesia yakni cacing laut. Upacara ritual penangkapan meci 
diselenggarakan setahun sekali pada April dan Mei. Upacara ritual tersebut sama dengan tradisi adat Bau Nyale yang diselenggarakan di Seger Kuta Lombok.

Berdasarkan fenomena tersebut terdapat beberapa permasalahan dalam pengembangan pariwisata di subdistrik Tutuala sebagai berikut; Apa saja potensi wisata yang dimiliki oleh Tutuala?, Bagaimana persepsi wisatawan terhadap pengembangan pariwisata di Tutuala?, Bagaimanakah strategi dan program pengembangan potensi pariwisata di Tutuala?

\section{Teori dan Metode}

Penelitian menggunakan motode kualitatif yaitu metode penelitian yang digunakan pada kondisi obyek yang alamiah, dimana peneliti adalah sebagai instrument kunci. Pengambilan responden dan informan sumber data yang dilakukan secara purposive sampling dan sampling incidental dengan teknik pengumpulan data observasi, wawancara, penyebaran angket dan dokumentasi, analisis data bersifat kualitatif dan hasil penelitian kualitatif lebih menekankan magna dari pada generalisasi (Sugiyono. 2013). Pendekatan ini digunakan untuk menjabarkan berbagai potensi wisata yang dimiliki oleh subdistrik Tutuala, bagaimana persepsi wisatawan tentang pengembangan pariwisata di subdistrik Tutuala serta startegi dan program pengembangan pariwisata di subdistrik Tutuala. Selain itu digunakan pula analisis SWOT, yakni strengths (kekuatan), weaknesses (kelemahan), opportunities (peluang) dan threats (ancaman).

Data dan informasi yang diolah sesuai dengan jenis data dan kemudian dianalisis secara deskriptif untuk mendapatkan pemaparan tentang inti permasalahan. Kemudian hasil penelitian disajikan secara formal dalam bentuk table, grafik, gambar, photo dan uraian mengenai pengembangan pariwisata subdistrik Tutuala sebagai sebuah destinasi wisata. Proses ini merupakan tahap akhir dalam rangkaian proses penelitian dengan tetap mengacu pada tujuan dan model penelitian.

\section{Karakteristik Subdistrik Tutuala}

Tutuala adalah nama sebuah suco dan subdistrik di Distrik Lautém Timor- Leste. Suco Tutuala terdiri dari 4 Aldeia / Desa, yaitu: Loro, Pitileti, Chailoro dan Vero. Tutuala adalah area utama penutur Bahasa Fataluku di Timor Leste, bersama dengan Lautém dan Fuiloro. Berdasarkan sensus penduduk tahun 2010, jumlah penduduk di Subdistrik Tutuala sebanyak 1.339 jiwa, yang terdiri dari 641 laki-laki dan 698 perempuan. (Tabel 4.1).

\subsection{Potensi Wisata di Subdistrik Tutuala}

Potensi pariwisata Subdistrik Tutuala, didukung oleh lokasinya yang strategis dalam lingkup kepariwisataan distrik Lautem. Pada lingkup 
Tabel 4.1 Jumlah Penduduk Subdistrik Tutuala

\begin{tabular}{llcccc}
\hline & & \multicolumn{3}{c}{$\begin{array}{c}\text { Jumlah penduduk Distrik Tutuala } \\
\text { menurut pembagian wilayah Subdistrik dan } \\
\text { Nenis kelamin }\end{array}$} \\
\cline { 3 - 5 } & \multirow{2}{*}{ Aldeia } & \multicolumn{3}{c}{ Jumlah penduduk } \\
\cline { 2 - 5 } & KK (Orang) & Laki-laki & Perempuan & Total \\
\hline 1 & Pitiliti & 136 & 303 & 356 & 659 \\
2 & Chailoro & 43 & 89 & 100 & 189 \\
3 & Loro & 42 & 114 & 119 & 263 \\
4 & Vero & 36 & 105 & 123 & 228 \\
& \multicolumn{1}{c}{ Total } & 257 & 641 & 698 & 1,339 \\
\hline
\end{tabular}

Sumber: (DNE, Sensus Penduduk 2010)

kepariwisataan nasional, subdistrik Tutuala merupakan salah satu lokasi yang paling ujung di Timor-Leste. Kedekatannya dengan pusat kota distrik Lautem menjadikan subdistrik Tutuala sebagai salah satu destinasi pariwisata unggulan secara nasional yang memiliki potensi alam dan sejarah.

Potensi-potensi alam yang dimiliki subdistrik Tutuala antara lain sebagai berikut;

\section{Pantai Valu}

Pantai Valu merupakan objek wisata andalan masyarakat Tutuala yang banyak dikunjungi wisatawan. Perjalanan menuju lokasi Valu \pm 1 jam dari pusat kota Lautem. Pantai Valu memiliki keindahan pasir putih serta terdapat juga beberapa simbol-simbol kepercayaan berupa batu-batuan yang letaknya berdekatan dengan lokasi pantai tersebut. Di samping menikmati keindahan pantai Valu dapat juga dilihat indahnya pulau Jaco yang jaraknya meski terpisah. Untuk menuju pantai Valu harus menggunakan mobil pribadi sebab hingga saat ini belum tersedianya kendaraan umum menuju lokasi tersebut dikarenakan kondisi jalan yang tidak bagus (tidak beraspal). Salah satu fasilitas pendukung di daerah tujuan wisata pantai Valu yaitu: akomodasi, perahu yang mengantarkan wisatawan apabila ingin mengelilingi pulau Jaco (Foto 1 Pantai Valu).

\section{Pulau Jaco}

Pulau Jaco merupakan salah satu pulau dari dua pulau yang ada di negara Timor-Leste. Pulau ini terletak paling timur atau paling ujung memiliki luas $12 \mathrm{~km} 2$. Pulau ini dijuluki sebagai pulau yang terunik dan tersakral di Timor-Leste sebab terdapat atau ditumbuhi oleh pohon asam dan beberapa jenis tanaman lainnya. Binatang yang hidup di pulau ini adalah musang, rusa, penyu, dan jenis-jenis burung salah satunya adalah burung kakatua. Dengan kekayaan alam yang dimiliki di pulau tersebut hingga saat ini pemerintah Timor-Leste mengeluarkan peraturan untuk melindungi kekayaan yang dimiliki berdasarkan keputusan pemerintah 

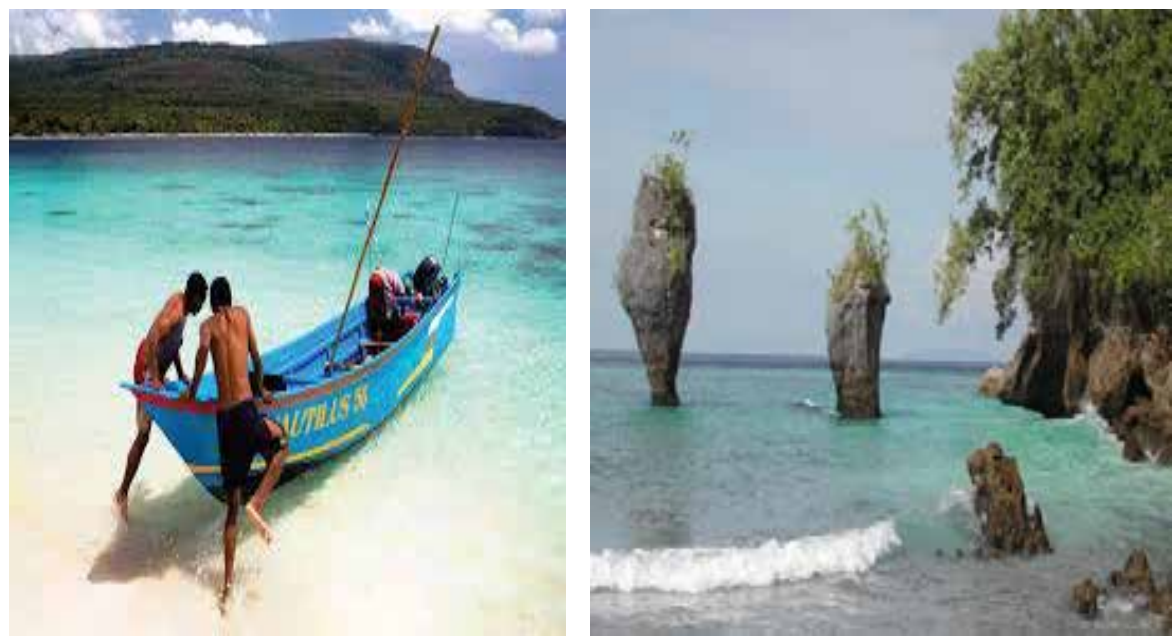

Foto 1. Pemandangan Pantai Valu.

RDTL No.5/2004 tentang peraturan umum penangkapan ikan. UNTAET tahun 2000 dalam regulasi nomor 2000/19, Jaco dijadikan sebagai kawasan perlindungan taman nasional. Salah satu aksesibilitas untuk menuju pulau Jaco yaitu menggunakan perahu yang disediakan oleh masyarakat Tutuala dengan tarif \$10 antarjemput. Pulau Jaco tidak dapat dihuni karena tidak tersedia fasilitas penunjang untuk mendukung aktivitas di pulau tersebut, hanya saja dapat dinikmati panorama alam di sekeliling pulau yang dimulai dari pagi sampai sore (BirdLife International, 2007). (Foto 2 Pulau Jaco).

\section{Goa Ili kere-kere}

Tutuala merupakan salah satu daerah yang kaya akan alam dan budaya, sebab salah satu keunggulan alam Tutuala yaitu Goa Ili kere-kere. Goa ini di perkirakan sekitar 43.00o tahun SM terdapat berbagai lukisan dinding hasil peninggalan manusia jaman dahulu yang mencermikan asal usul nenek moyang Timor-Leste. Jarak yang ditempuh untuk mencapai goa tersebut \pm 30 menit di sekitar Tutuala karena berjalur menuju pantai Valu. Tempat ini diyakini oleh masyarakat setempat sebagai tempat sakral untuk melakukan upacara ritual. Hingga saat ini masyarakat setempat menggunakan Goa Ili kere-kere untuk pemujaan roh sebagai simbol berkat apa yang mereka dapat sebagai sumber kehidupan sehari-hari. Meski Goa Ili kere-kere belum dikemas sedemikian rupa, namun hingga saat ini sudah banyak diminati oleh para wistawan untuk berkunjung. Goa Ili kere-kere merupakan satu-satunya goa yang yang ada di Timor-Leste dan menjadikan prioritas oleh kementrian pariwisata dalam mempromosikan tempat tersebut sabagai salah satu daya tarik wisata bersejarah (Foto 3 Goa Ili kere-kere). 

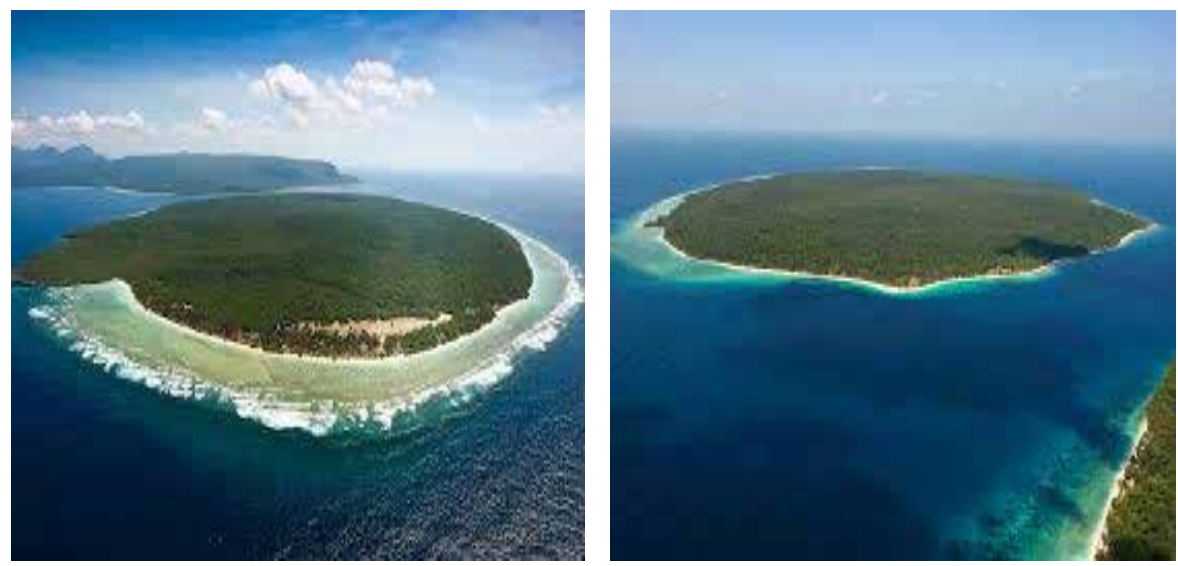

Foto 2. Pemandangan Pulau Jaco
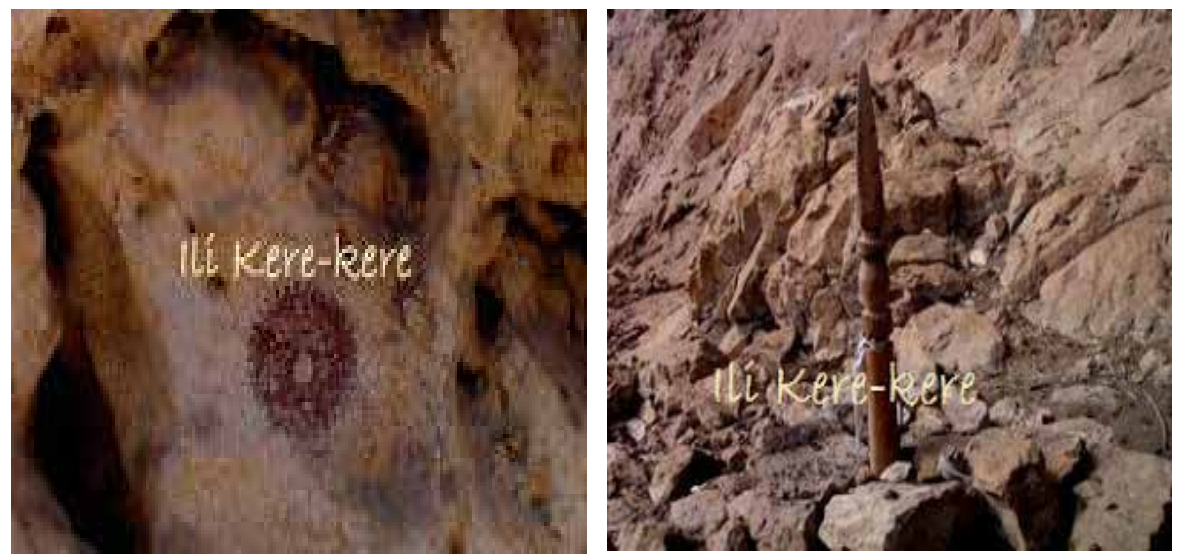

Foto 3. Goa lli kere-kere.

\section{Taman Nasional Nino Koni Santana.}

Taman Nasional yang luasnya mencapai 125,6 ha tersebut berlokasi di ujung paling timur Timur Leste. Termasuk juga sebuah pulau kecil, yaitu Pulau Jaco yang terdiri atas kawasan darat seluas 68 ha dan sisanya kawasan perairan laut. Taman nasional yang mencakup satu-satunya kawasan hutan hujan basah di Pulau Timor ini, digabungkan dengan kawasan burung (bird areas) Loré, Monte Paitchau, Lake Ira Lalaro, dan Pulau Jaco, yang sebelumnya telah ditetapkan oleh Bird Life International. Selain mencakup kawasan hutan, taman nasional ini juga mencakup kawasan permukiman yang mencakup desa-desa Com, Tutuala, Méhara, dan Maupitine. Taman Nasional dijadikan tempat rekreasi bagi wisatawan lokal serta Trekking dan kamping bagi wisatawan mancanegara (Foto 4 Peta Taman Nasional Nino Koni Santana). 


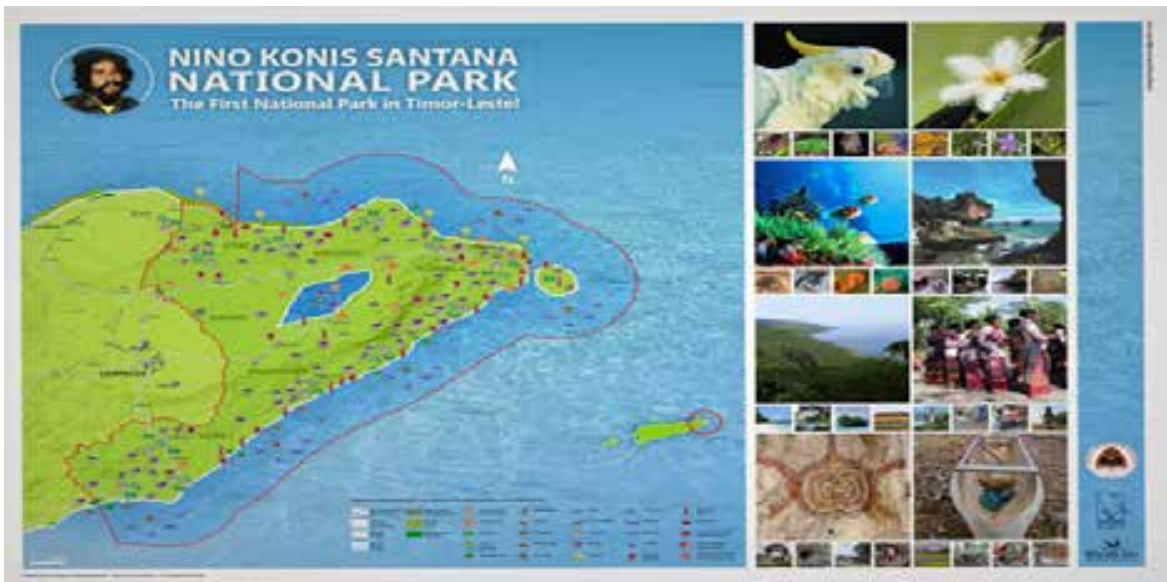

Foto 4. Peta Taman Nasional Nino Koni Santana
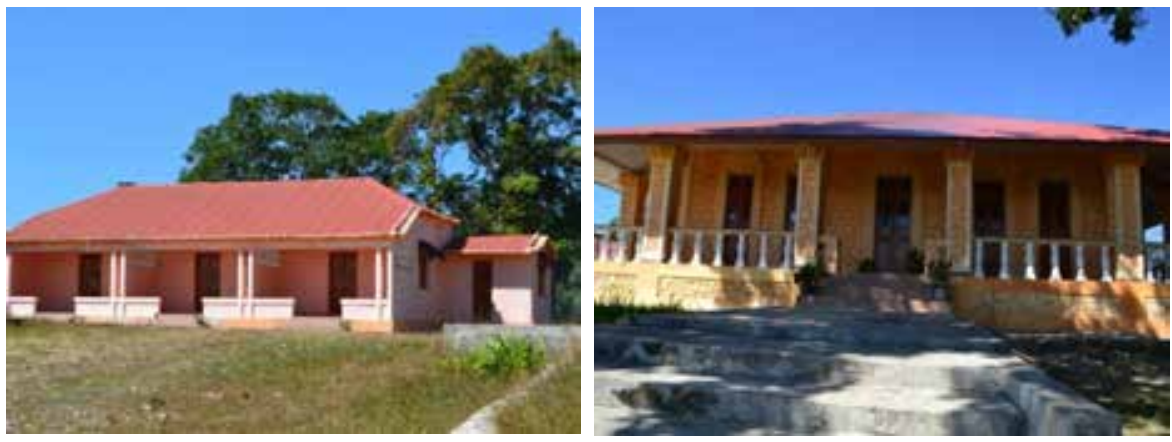

Foto 5. Pousada Tutuala

Potensi sejarah dan budaya yang dimiliki oleh Subdistrik Tutuala seperti; a. Bangunan-bangunan bersejarah kolonial Portugis (Pousada),

Beberapa peninggalan bersejarah berupa bangunan lainnya adalah sisa-sisa peninggalan Portugis, seperti losmen (pousada). Lokasi ini merupakan tempat peristirahatan para tentara Portugis. Awal mula losmen tersebut di dirikan, daerah tersebut merupakan tanah kuburan. Pemerintah Portugis menjadikan tempat tersebut sebagai bangunan losmen atau tempat peristrahatan. Bangunan-bangunan yang berada di sekelilingi daerah tersebut berupa model-model Portugis dan pemerintah Timor-leste hanya merenovasi dan tidak mengantikan arsitekturnya. Pousada Tutuala kini dikemas sebagai salah satu tempat penginapan bagi para wisatawan (Foto 5 Pousada).

\section{b. Upacara Ritual Tradisional}

Masyarakat Tutuala memiliki kepercayaan hingga saat ini masyarakat tersebut masih mempraktikkan budayanya sebagai simbol kepercayaan dalam memuja atas berkat yang diberikan-Nya. Saat ini kepala administratif Tutuala dalam perencanaanya sudah mengagendakan beberapa upacara 

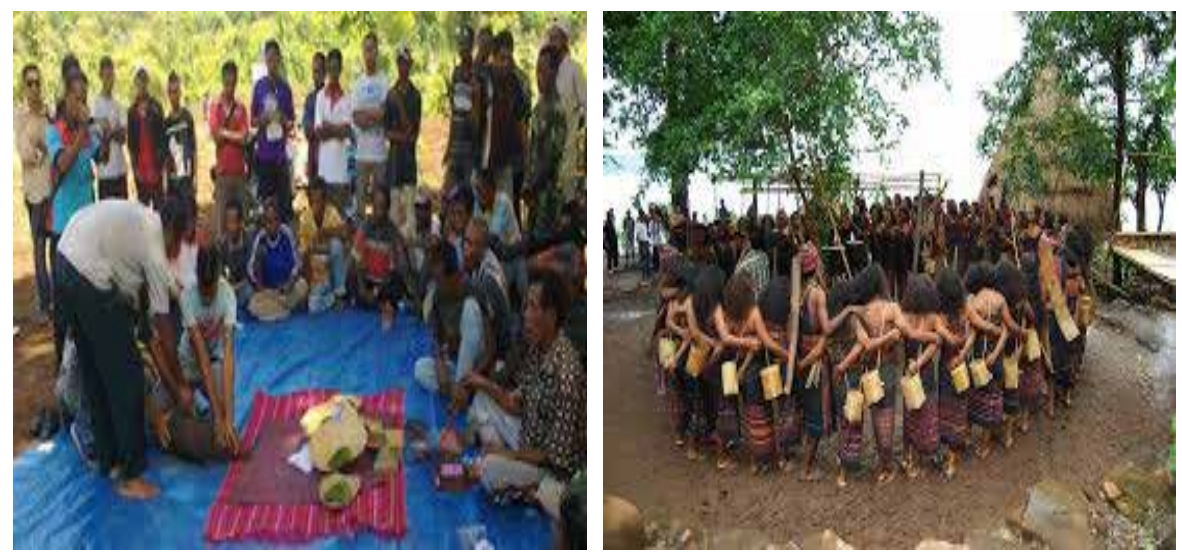

Foto 6. Upacra Ritual Tradisonal

ritual di Tutuala yang akan dijadikan sebagai atraksi wisata, di antaranya: ritual meci, uma lulik, dan juga akan diadakan beberapa event budaya seperti Ritual Meci dan Jaco festival yang diselenggarakan pada bulan April dengan diselenggarakannya perlombaan seperti Diving dan diadakan juga pertujukkan berbagai budaya seperti pakaian, makanan, tari-tarian dari berbagai subdistrik yang ada di Distrik Lautem (Foto 6 Upacara Ritual).

c. Kerajinan Tenunan Kain (Tais).

Salah satu icon atau cenderamata khas di Tutuala yaitu tais yang merupakan tenunan kain dengan beragam variasi. Tais merupakan industri rumah tangga yang dihasilkan oleh masyarakat setempat. Keunikan dari pembuatan tais ini menggunakan alat-alat tradisional dan bahan alam, proses pembuatan tais memakam waktu \pm 3 sampai 5 hari tergantung ukuran dan model yang diproduksi dengan harga yang bervariasi dari $\$ 5$ sampai \$50. Kegunaan tais tersebut bagi masyarakat Tutuala sangatlah mengandung banyak fungsi yang digunakan untuk upacara-upacara adat, upacara diplomat, dan jenis upacara lainnya. Tais dijadikan sebagai suatu produk pariwisata yakni khususnya di Distrik Lautem yang sering diadakan pameran-pameran tais untuk dipromosikan ke wisatawan. Bukan saja Tais yang diproduksi tetapi masih ada bahan tenunan tradisional lainnya seperti bote, lafatik, dan jenis lainnya (Foto 7 Tenunan Tais).

\section{Persepsi Wisatawan tentang pengembangan Subdistrik Tutuala.}

\section{a. Karakteristik Responden}

Dalam penelitian ini wisatawan yang dipilih sebagai responden sebanyak 26 responden yang terdiri dari 17 responden wisatawan internasional dan 9 responden wisatawan internasional. Hasil menunjukkan bahwa (34.6\%) adalah wisatawan internasional dan wisatwan domestik (65.4\%) dengan 

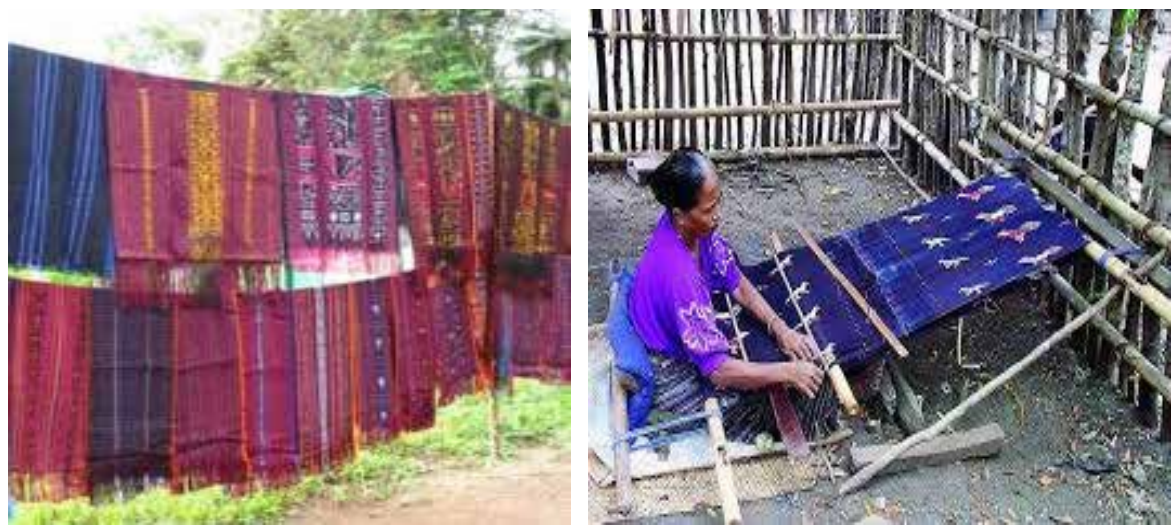

Foto 7. Kerajinan tangan tenunan Tais masyarakat Tutuala

perbandingan jender adalah laki-laki (53.85\%) dan perempuan (46.15\%), dengan usia rata-rata 20-30 (53.8\%) yang berasal dari Timor-Leste (65.4\%), Australia (26.9\%), Portugal (7.7\%). Profesi responden adalah pegawai negeri (57.7\%), pegawai swasta (23.1\%), $11.5 \%$ pensiunan (11.5\%), pelajar (3.8\%) dan petani (3.8\%) .

Persepsi wisatawan berdasarkan waktu kunjungan di Tutuala, persentase tertinggi wisatawan meluangkan waktu kunjungan satu kali (42.31\%), tiga kali (7.69\%). Berdasarkan lama kunjungan wisatawan ke Tutuala, mayoritas tinggal di Tutuala selama dua hari (57.69\%), satu hari (23.08\%), satu minggu (15.38\%), lebih dari satu bulan (3.85\%). Salah satu alas an para wisatawan hanya meluangkan waktunya sedikit di daerah tujuan wisata Tutuala karena minimnya fasilitas penunjang pariwisata seperti; jalan raya, penginapan, transportasi dan lain sebagainya

b. Persepsi wisatawan terhadap Daya Tarik Wisata.

Potensi wisata Tutuala yang memikat wisatawan adalah, alam (61.54\%), pantai (30.77\%), sejarah dan budaya (3.85\%), flora dan fauna (3.85\%). Dapat disimpulkan mayoritas pariwisata yang dimiliki oleh Subdistrik Tutuala lebih banyak didominasi oleh alam, pantai, hutan, taman dan Goa, sehingga menarik wisatawan berkunjung untuk melakukan berbagai aktivitas seperti trakking dan diving.

c. Persepsi wisatawan tentang Pengembangan Potensi.

Pengembangan potensi pariwisata di Tutuala dimana mayoritas sikap wisatawan sangat setuju (88.46\%), setuju (11.54\%) jika Tutuala dikembangkan sebagai daya tarik wisata karena memiliki beragam alam, sejarah dan budaya yang masih original, salah satunya seperti lukisan dinding Goa Ili kere-kere. 


\section{d. Persepsi wisatawan mengenai Motivasi Mengunjungi Tutuala}

Berbagai ragam motivasi wisatawan mengunjungi Tutuala diantaranya untuk liburan (53.85\%), rekreasi (30.77\%), kamping (7.69\%), penelitian (7.69\%). Menurut salah satu wisatawan internasional mengatakan bahwa memilih Tutuala sebagai tempat rekreasi karena Tutuala memiliki keindahan alam dan keaslian sejarah dan budaya yang begitu indah seperti salah satunya adalah Goa Ili kere-kere.

e. Persepsi wisatawan terhadap Masyarakat Lokal.

Respon wisatawan tentang manfaat ekonomi yang dimiliki oleh masyaraka lokal di Tutuala bagus (46.15\%), sangat bagus (26.92\%), sangat tidak bagus (15.38\%), cukup bagus (11.54\%). Salah satu manfaat ekonomi sebagai mata pencaharian masyarakat Tutuala adalah pertanian, berupa padi, sayuran dan buah-buahan sebagai lahan bisnis dalam kehidupan sehari-hari.

\section{f. Persepsi wisatawan Terhadap Keadaan Fisik dan Nonfisik.}

Persepsi wisatawan tentang keadaan Nonfisik yang dimiliki Tutuala salah satunya adalah mengenai atraksi wisata yang dimiliki Tutuala, sangat bagus (38.46\%), sangat tidak bagus (3.85\%). Persepsi wisatawan sangat bagus terhadap atraksi Tutuala, sebab Tutuala memiliki berbagai sejarah dan budaya yang beragam dari masing-masing subdistrik seperti, bahasa, pakaian adat, upacara adat serta diselenggarakan atraksi wisata seperti Meci, Jaco festival.

Berdasarkan persepsi wisatawan tentang keadaan fisik salah satunya adalah transportasi menuju Tutuala, cukup bagus (34.62\%) dengan persentase tertinggi dan sangat bagus (11.54\%). Salah satu hambatan sampai saat ini adalah transportasi umum menuju daerah tujuan wisata Tutuala yang belum tersedia, sehingga menyebabkan minimnya wisatawan yang berkunjung dan belum tersedianya juga akses jalan yang begitu bagus seperti aspal karena sampai saat ini akses jalan menuju Tutuala kurang memadai.

\section{Strategi dan Program Pengembangan Pariwisata di Subdistrik Tutuala}

Strategi pariwisata di Tutuala berdasarkan kombinasi faktor internal berupa kekuatan dan kelemahan serta faktor eksternal berupa peluang dan ancaman.

a. Kekuatan

Kekayaan alam berupa; Pantai Valu, Pulau Jaco dan Taman Nino konis Santana, sejarah berupa; Goa Ili Kere-kere, Pousada Tutuala, budaya; upacara ritual meci, upacara penyembahan kurban di pulau Jaco, upacara panen jagung, tei fai, lipal fai, mua navarama, uma lulik, ai-tos, aya ceru, Ili Kere-kere. 


\section{b. Kelemahan}

Objek wisata belum tertata secara baik, kurangnya sarana dan prasarana penunjang pariwisata, kurangnya sumber daya manusia di bidang pariwisata, kurangnya promosi pariwisata khususnya Tutuala, belum diterapkannya undang-undang pariwisata, kurangnya permodalan /inverstasi masyarakat, kurangnya perhatian pemerintah pusat pariwisata untuk program pengembangan di Tutuala, belum adannya lembaga terkait pengolahan pariwisata di desa Tutuala, belum adanya otonomi daerah.

\section{c. Peluang}

Meningkatnya Wisatawan di desa Tutuala, adanya pertumbuhan ekonomi masyarakat di desa Tutuala dari hasil pertanian dan perikanan, meningkatnya kemajuan teknologi seperti transportasi dan telekomonikasi, adanya trend pariwisata dunia kearah pariwista alternative, back to natural yakni Tutuala adalah salah satu bentuk pariwisata yang sangat mendukung, sejalang dengan semakin mengglobalnya wacana pemasaran, adanya hubungan kerja sama bilateral.

\section{d. Ancaman}

Kondisi keamanan yang belum melebar luas di sudut-sudut objek wisata di Tutuala, kurangnya dukungan atau perhatian dari pemerintah pusat, belum adanya sarana dan prasarana penunjang pariwisata, belum adanya otonomi daerah, persaingan destinasi wisata yang sejenis, penebangan liar (Perburuan dan penakapan binatang liar).

Hasil analisis SWOT mengenai faktor-faktor internal dan eksternal yang ada di daerah tujuan wisata Tutuala menunjukkan bahwa letak posisi Tutuala lebih banyak berada pada kelemahan (Weakness) dan ancaman (Treasths). Menurut Rangkuti (2013) bahwa kombinasi komponenkomponen SWOT merupakan strategi-strategi yang mendukung suatu program yang dirancang. Maka dari itu, untuk meminimalkan kelemahan untuk menghindari ancaman yang dihadapi peneliti merumuskan beberapa program dan strategi pengembangan terhadap daerah tujuan wisata Tutuala sebagai berikut:

\section{Perencanaan strategi dan program pengembangan pariwisata Tutuala}

a. Strategi S-o (Strength Opportunity).

Strategi ini dibuat untuk memanfaatkan seluruh kekuatan secara maksimal guna memanfaatkan peluang. Antara lain: Strategi pengembangan objek dan daya tarik wisata dengan program pemetaan kawasan pariwisata, program inventarisasi daya tarik wisata, program promosi potensi wisata. Strategi tersebut dibuat sebab sampai saat ini daerah tujuan wisata Tutuala 
Gambar 1 Program dan Strategi Pengembangan Pariwisata Tutuala

\begin{tabular}{|c|c|c|}
\hline & STRATEGI & PROGRAM \\
\hline S-O & $\begin{array}{l}\text { Strategi pengembangan objek dan daya } \\
\text { tarik wisata }\end{array}$ & $\begin{array}{l}\text { 1. Program pemetaan kawasan pariwisata } \\
\text { 2. Program inventarisasi daya tarik wisata } \\
\text { 3. Program promosi potensi wisata }\end{array}$ \\
\hline S-T & $\begin{array}{l}\text { Strategi peningkatan keamanan dan } \\
\text { kenyamanan }\end{array}$ & $\begin{array}{l}\text { 1. Program pelaksanaan siskamling dan } \\
\text { kerjasama pihak keamanan } \\
\text { 2. Program pembangunan pos-pos }\end{array}$ \\
\hline W-O & Strategi penataan objek wisata & $\begin{array}{l}\text { 1. Program pembuatan paket wisata } \\
\text { 2. Program pembangunan sarana dan } \\
\text { prasarana penunjang pariwisata }\end{array}$ \\
\hline W-T & $\begin{array}{l}\text { Strategi pengembangan kelembagaan } \\
\text { dan SDM }\end{array}$ & $\begin{array}{l}\text { 1. Peningkatan sumber daya manusia } \\
\text { 2. Program pembentukan kelembagaan } \\
\text { pengelola daya tarik wisata } \\
\text { 3. Penyuluhan sadar wisata. }\end{array}$ \\
\hline
\end{tabular}

Keterangan : S-o (Strength Opportunity). S-T (Strength Opportunity). W-O (Weaknes Opportunities). W-T (Weakness Threats).

belum di inventarisasi dengan baik seperti belum tersedianya sarana penunjan antara lain; Toilet umum, tempat sampah dan lain sebagainya.

\section{b. Strategi S-T (Strength Opportunity)}

Strategi menggunakan kekuatan yang dimiliki untuk mengatasi ancaman yang mungkin timbul berupa, strategi peningkatan keamanan dan kenyamanan seperti: program pelaksanaan siskamling dan kerjasama pihak keamanan program pembangunan pos-pos. Strategi ini dibuat untuk mengantisipasi timbulnya permasalahan di daerah tujuan wisata Tutuala dan memberikan kenyamanan bagi wisatawan, karena Tutuala sampai saat ini belum adanya pihak keamanan yang mendirikan pos-pos di daerah tujuan wisata tersebut jadi sangat mudah bagi siapapun yang berkunjung bisa memicuh hal-hal yang tidak diinginkan.

\section{c. Strategi W-O (Weaknes Opportunities)}

Strategi ini diterapkan berdasarkan pemanfaatan peluang yang ada dengan cara meminimalkan kelemahan yang ada, Strategi penataan objek wisata dengan program pembuatan paket wisata dan program pembangunan sarana dan prasarana penunjang pariwisata. Strategi ini dibuat untuk mempromosikan pariwisata khusunya di Tutuala agar lebih dikenal masyarakat luas, sebab hingga saat ini hanya ada pihak-pihak tertentu yang baru mempromosikan Tutuala salah satunya adalah Haburas Fundation.

\section{d. Strategi W-T (Weakness Threats).}

Strategi ini didasarkan pada kegiatan yang sifatnya defensif dan berusaha meminimalkan kelemahan yang ada untuk menghindari ancaman. Strategi pengembangan kelembagaan dan SDM seperti peningkatan sumber daya manusia, program pembentukan kelembagaan pengelola daya tarik wisata 
dan penyuluhan sadar wisata. Startegi ini dibuat untuk meningkatkan kapasitas dan profesionalisme SDM karena masih minimnya SDM dalam mengembangakan pariwisata di Timor-Leste khusunya Tutuala.

Sampai saat ini, pengembangan pariwisata Tutuala yang tercantum pada rencana jangka panjang 2015-2022 yang terfokus pada tingkat lokal, regional dan nasional. Subdistrik Tutuala dalam pengembangan dan perencanaan pariwisata untuk tahun 2015 sampai 2022, pemerintah menetapkan bahwa salah satu pengembangan yang dilaksanakan adalah; jalan raya, air bersih, listrik, telekomunikasi, hotel dan restoran serta atraksi budaya seperti tarian tradisional, kuliner dan ritual Goa Ili kere-kere. Memepertimbangkan hasil penelitian, pembangunan pariwisata Tutuala memiliki potensi pengembangan untuk tingkat internasional yang dapat mendatangkan wisatawan internasional dari berbagai Negara seperti Negara asean; Indonesia, Australia dan Negara eropa; inggris, Portugal dan America.

Tutuala sebagai salah satu destinasi wisata yang unik di Negara Timor-Leste, pemerintah daerah terus berupaya mengembangkan perekonomian masyarakat dengan menitikberatkan pada jasa industri yang ada dengan mengoptimalkan pemanfaatan potensi yang ada, termasuk potensi pariwisata. Salah satu alternatif upaya optimalisasi pengembangan pariwisata daerah adalah melalui pengembangan Sub-distrik Tutuala sebagai salah satu destinasi pariwisata internasional. Upaya pengembangan Tutuala sebagai suatu destinasi pariwisata internasional membutuhkan kerjasama dan koordinasi yang baik seluruh stakeholder kepariwisataan daerah di Tutuala. Pemerintah Sub-distrik Tutuala berkomitmen dan mendukung pengembangan pariwisata di wilayahnya melalui departemen perencanaan dan pengembangan pariwisata, termasuk untuk pengembangan Sub-distrik Tutuala sebagai destinasi pariwisata internasional.

\section{Simpulan dan Saran}

Berdasarkan uraian diatas, maka dapat disimpulkan sebagai berikut. Potensi wisata di Tutuala memiliki beranekaragam baik berupa alam: pantai Valu, pulau Jaco, Goa Ili Kere-kere, taman nasional nino koni santana, bangunan bersejarah pousada. Potensi budaya berupa upacara ritual tradisonal dan kerajinan tenunan kain. Dalam pengembangan pariwisata di Tutuala, hasil penelitian presepsi wisatawan menujukkan sikap sangat setuju (88.46\%) jika dikembangkan sebagai daerah tujuan wisata, sebab Tutuala memiliki potensi-potensi pariwisata yang sangat bagus (92.31\%). Hal ini menunjukkan bahwa wisatawan memiliki pandangan yang positif terhadap pengembangan pariwisata di Tutuala. Selain itu juga, wisatawan menginginkan pengembangan aksesibilitas menuju ke Tutuala sebab mayoritas wisatawan menjawab kurang bagus dengan presentase (34.62\%) terhadap akses jalan menuju Tutuala. 
Dapat dikatakan bahwa jika pariwisata Tutuala dikembangkan dapat diperhatikan sarana dan prasarana kepariwisataan yang ada. Dari hasil analisis SWOT, faktor-faktor internal dan eksternal yang ada di daerah tujuan wisata Tutuala menunjukkan bahwa letak posisi Tutuala lebih banyak berada pada kelemahan dan ancaman. Untuk meminimalkan kelemahan yang ada dan untuk menghindari ancamannya, berikut dirumuskan beberapa strategi dan program pengembangan daerah tujuan wisata Tutuala di antaranya adalah; statrategi pengembangan objek dan daya tarik, strategi promosi pariwisata, strategi sarana dan prasaran penunjang pariwisata, starategi peningkatan keamanan dan kenyamanan, strategi peningkatan kelembagaan dan SDM, strategi sosialisasi pariwisata. Dari beberapa strategi tersebut maka di rumuskan juga beberpa program yang diantaranya; program pemetaan potensi wisata, program inventarisasi objek dan daya tarik wisata, program pembangunan sarana dan prasarana penunjang pariwisata, program pelaksanaan siskamling, program pembentukan kelembagaan dan pendidikan dibidang pariwisata dan program penyuluhan sadar wisata.

Berdasarkan pembahasan dan simpulan maka dapat disarankan beberapa hal kepada berbagai pihak antara lain sebagai berikut; Pariwisata di Tutuala, pemerintah hendaknya mengarahkan pada pembangunan pariwisata mulai dari pembangunan sarana dan prasarana, pengembangan sumber daya manusia di bidang pariwisata dan membuka peluang yang lebih banyak bagi pelaku pariwisata untuk turut berpartisipasi dalam pengembangan pariwisata di Timor-Leste khususnya subdistrik Tutuala. Masyarakat subdistrik Tutuala, mempertahankan nilai-nilai budaya yang ada di Tutuala dengan Menjaga dan memelihara lingkungan dan kekayaan yang dimiliki baik itu alam maupun peninggalan-peninggalan lainnya. Dengan keterbatasan penelitian ini mengenai variabel pengembangan pariwisata di Tutuala, disarankan kepada peneliti berikutnya untuk meneliti variable lainnya seperti SDM untuk pengelola objek wisata, managemen pengelola pariwisata dan promosi pariwisata, agar lebih mengetahui strategi pengembangan yang lebih konkret dan lebih luas akan pengetahuan mengenai Tutuala.

\section{Daftar Pustaka}

Alves, G. 2012. "Planu Desenvolvimento Turizmu ba Futuru”. Revista MTCI. Edisaun II, Pag 01-O8. Dili 2012.

Alwi, Hasan. Dan Sugono, Dendy. 2005. Kamus Bahasa Indonesia. Edisi ketiga. Jakarta: Balai Pustaka..

BirdLife International. 2007. Important bird areas in Timor-Leste. Cetakan pertama. Darwin.

De Carvalho Maria Soares, Glenda. 2012. "Pengembangan Parque Nacional Nino

Konis Santana Sebagai Daya Tarik Ekowisata di Desa Tutuala Sub-Distrik Tutuala Distrik Lautem Timor-Leste” (tesis); Denpasar: Universitas Udayana. 
Direccao Nasional de Estatistica. Sensus Populasaun no Uma Kain Timor-Leste. Vol 4 Dili Timor-Leste: DNE \& UNFPA.

Gama dos Santos, Cristovao. 2012 "Persepsi Wisatawan Tentang Pengembangan pariwisata di Suco Com, Sub-Distrik Lautem, Distrik Lautem” (Skripsi); TimorLeste :Dili Institute of Technology.

Gisela Q.C.F. 2013. "Pengembangan Pariwisata di Distrik Lautem Timor Leste" (tesis); Denpasar: Universitas Udayana.

Gondinho Cunha, Calistro. 2013. "Pengembangan Destinasi Ekowisata Air Panas Marobo di Desa Ilat Laun Kecamatan Bobonaro Kabupaten Bobonaro, TimorLeste”. (tesis); Denpasar: Universitas Udayana.

Hang, Chandaravuth and Song Sothun. 2011. Potential For Developing Tourism In Banteay Chhmar. Cambodia : Royal University of Agriculture, [Cited 2015 Aug. 25]. From: URL: http:/www.jurnalinternational.com/htm.

Hale da Silva Litwina, Adelfina. 2014. "Tantangan Pengembangan Potensi Wisata Pantai Haerliu Sebagai Obyek wisata Di Aldeia Cikara, Suco Com, Sub-Distrik Lautem, Distrik Lautem" (Skripsi); Timor-Leste: Dili Institute of Technology.

Hong, Chern-Wern and Chang, Ngai-Weng. 2010. Strength-weakness-opportunitiesthreats Analysis of Penang National Park for Strategic Ecotourism Management. Malaysia: University Sains Malaysia. [Cited 2015 Aug. 25]. From: URL: http:/www.jurnalinternational.com/htm.

http://manfaat.co.id/manfaat-pembangunan-ekonomiPost. Date: Wednesday o3rd, June 2015 / 04:29 Oleh : dr Yuli Kategori : Pendidikan . [Cited 2015 Aug. 25]. From: URL: http:/www.jurnalinternational.com/htm.

Kusmayadi dan Sugioyono, E. 2000. Metodologi Penelitian dalam Bidang Kepariwisataan. Jakarta: PT. Gramedia Pustaka Utama.

Lay, F. 2012. "Planu Desenvolvimento Turizmu ba Futuru”. Revista MTCI. Edisaun II, Pag 02-04. Dili 2012."

Map Showing Location of Sucos in Lautem District. [cited 2014 feb. 11]. From:Http:// www.mof.gov.tl/wpcontent/uploads/2011/10/lautem-suco-map.png.

Medina, C. 2015. Planu Estrategico de Desenvolvimentu do Turizmu Timor-Leste. Dili: MTACTL

Muljadi. A.J. 2012. Kepariwisataan dan Perjalanan. Edisi ke-3. Jakarta: Raja Grafindo Prasada.

NeTour. 2013. Cultural Tourism In Rusia. 35-37, [Cited 2015 Aug. 25]. From: URL: http:/www.jurnalinternational.com/htm.

Pitana, I Gde dan I Ketut S Diarta. 2009. Pengantar Ilmu Pariwisata. Yogyakarta : Andi.

Rangkuti, F. 2013. Analisis SWOT- Teknik Menbedah Kasus Bisnis. Jakarta: PT. Gramedia Pustaka Utama.

Sugiyono. 2013. Metode Penelitian Manajemen. Bandung: Alfabeta

Sukandarrumidi. 2002. Metodologi Penelitian. Yogyakarta: Gadjah Mada University Press. 
Sukarsa, I M. 1999. Pengantar Pariwisata. Badan kerja sama perguruan tinggi negeri Indonesia Timur.

Sunaryo, Bambang. 2013. Kebijakan Pembangunan Destinasi Pariwisata. Yogyakarta: Gava Media.

Soebagyo, P.J. 1999. Metode Penelitian dalam Teori dan Praktek. Jakarta: Rhineka cipta

Swantoro, Gamal. 1997. Perencanaan Produk Wisata. Yogyakarta: Gava Media

Yoeti, Oka. A. 2008. Perencanaan dan Pengembangan Pariwisata. Jakarta: Pradyana.

\section{Profil Penulis}

Tomas Pereira adalah alumnus Prodi Magister Kajian Pariwisata Unud tahun 2016. Tahun 2007 mengiktui kursus perhotelan selama 6 bulan di World Vision TimorLeste dapat mendapatkan predikat lulusan terbaik. Tahun 2008 mulai melanjutkan perkuliahan di Dili Institute of Technology (DIT) Timor-Leste dalam proses perkuliahan di tahun 2010 mendapatkan predikat Best Student in Tourism Faculty dan menyelesaikan studi S1 tahun 2012. Pada tahun 2013 mendapatkan beasiswa S2 yang diberikan oleh DIT untuk melanjutkan program magister kajian pariwisata di Universitas Udayana Denpasar dan menyelesaikan studinya di tahun 2016. Sekarang bekerja sebagai dosen di DIT. Email: tompereira658@gmail.com 